\title{
Morphological Effects of Stymjod Foliar Application on Medicago × varia T. Martyn
}

\author{
Jacek Sosnowski', Ewelina Toczyska' ${ }^{1}$, Milena Truba ${ }^{1 *}$ \\ 1 Department of Grassland and Green Areas Creation, Siedlce University of Natural Sciences and Humanities, \\ ul. Prusa 14, 08-110 Siedlce, Poland \\ * Corresponding author's e-mail: milena.truba@uph.edu.pl
}

\begin{abstract}
The aim of the study was to investigate how the foliar application of iodine, as well as its concentration in the working liquid, influence the growth of fresh and dry weight of plants, stems, leaves, roots and number of shoots and leaf laminae of sand Lucerne. The experiment was carried out in vases. The three plants that developed the largest number of leaves in the vase were left. The experimental factors as the plant growth regulator with the trade name Stymjod in three concentrations of $1.5 \%, 3 \%$ and $4.5 \%$ in the working liquid were introduced; the control involved distilled water. Two plant ap-plications were performed. The first one in 6 appropriate leaf phase and the second in the branching formation phase. A single dose of the working liquid was $50 \mathrm{ml}$ per vase. This dose of liquid caused the complete sprinkling of plants in a vase. The obtained results were statistically analyzed by means of analysis of variance. The experiment showed that the concentration of Stymjod in the working liquid is very important. It is difficult to say which concentrations gave the best results in cultivating sand lucerne. The present studies demonstrated that Stymjod applied foliarly at $4.5 \%$ concentration significantly affected the growth of stems and leaf blades. Additionally, $1.5 \%$ concentration increased the weight of fresh matter and dry matter of roots. The experiment showed that the effects of Stymjod application to hybrid alfalfa depended on its dose. It is difficult, however, to clearly state which concentration produced the best results so further research in this area is needed.
\end{abstract}

Keywords: iodine, alfalfa, plant morphology, stem, leaves, mass of plants.

\section{INTRODUCTION}

According to the World Health Organization (Reducing salt intake in populations. Report of a WHO Forum and Technical Meeting 2007) iodine is an essential nutrient in the human body. It rarely occurs in nature and is found in plants in very small quantities; hence, it is often called a trace element. Iodine helps to increase the plant resistance to stress and fungal diseases (Wierzbińska et al., 2011). Therefore, to increase the iodine content in plants, a new process called iodine biofortification has been developed. It is based on enriching, saturating, and nourishing crops with this micronutrient (Blasco et al., 2008; Dai et al., 2006; Mackowiak and Gross1, 1999; Strzetelski et al., 2010 a, b; Zhu et al., 2003).

There are a number of factors affecting iodine uptake by plants. It depends largely on the species, soil moisture, and temperature. It turned out that cereals had the lowest ability to take up iodine from soil. Iodine forms soluble in water are absorbed by the root system best, and their uptake from soil is 2500 times more intense. The most favourable results were obtained using foliar application because the iodine dissolved in water penetrates cuticle pores. Positively charged iodine ions are easily available to plants, and they are directly absorbed by root hairs as well as through the cell membrane of the aboveground parts without modification (Romanowska-Duda et al. 2018). In order to supply plants with this micronutrient, an iodine concentrate called Stymjod was used. It is a mixture of this chemical element with water $(80 \mathrm{mg}$ of iodine per 1 litre of $\mathrm{H}_{2} \mathrm{O}$ ). Weng et al. (2008) as well as Dai et al. (2006) found that foliar application of an iodine concentrate brought the best results. In the same 
experiment, it turned out that soil application was nearly as effective as foliar application.

According to many authors (Ilieva and Vasileva, 2013; Kallenbach et al., 2002; Lu et al., 2017; Peoples, 2001; Pietrzak and Grela, 2013; Shen et al., 2013; Vasileva et al. 2011; Wilczek et al., $2005 \mathrm{a}, \mathrm{b}$ ) alfalfa is a valuable plant from the economic point of view because of its favourable chemical composition with the content of protein, fibre, and carotenoids. Peoples (2001) point out that the nutritional value of a plant depends on many factors, including, among others, the type of soil on which it is grown, the amount of precipitation, fertilizer doses, as well as its development stage during the harvest. Alfalfa is mainly used for animal feed in the form of dried fodder, forage, silage, or hay, all of them with high content of well digestible protein. According to Pietrzak and Grela (2013) the plant is also used in medicine because of its anticancer, antifungal, detoxifying, and diuretic properties. It strengthens the immune system, slows the cell aging process, and alleviates rheumatic pains. Alfalfa contains many vitamins, enzymes, and other components necessary for the proper functioning of the human body. In addition, the above-mentioned authors found that when used as a dietary supplement, alfalfa causes better absorption of calcium, iron, and other nutrients such as protein and carbohydrates. It also increases the resistance of the body and produces a feeling of relaxation (Gawel and Grzelak, 2013). Moreover, Alfalfa is a species that very positively responds to foliar application of fertilizers (Godlewska and Ciepiela, 2018; Sosnowski et al., 2017; Sosnowski et al., 2019).

The aim of the paper was to determine the effects of foliar application of different concentrations of Stymjod on the morphological characteristics of hybrid alfalfa (Medicago x varia $\mathrm{T}$. Martyn) var. Kometa. The research was to study the effect of different doses of the fertilizer on the number of stems and leaf blades and on the growth of fresh and dry matter of stems, leaves, roots, and the whole plant.

\section{MATERIAL AND METHODS}

\section{Experimental conditions}

A pot experiment was conducted in 2017 in the breeding room of the Department of Grassland and Green Area Creation, Siedlce University of Natural Sciences and Humanities. The conditions of the experiment were as follows: the temperature of $24 \pm 2^{\circ} \mathrm{C}$ (in light) and $16 \pm 2^{\circ} \mathrm{C}$ (in darkness); soil moisture $60 \%$ of field water capacity; the intensity of light of $200 \mu \mathrm{mol} \mathrm{m} \mathrm{m}^{-2} \mathrm{~s}^{-1}$ (obtained with high pressure sodium lamps); the photoperiod of 16 hours in light. Medicago x varia T. Martyn, var. Kometa was used as a test plant grown in pots with a height of $300 \mathrm{~mm}$ and the $200 \mathrm{~mm}$ diameter of the base.

The experiment was replicated three times and completely randomised with control units. The pots were filled with $5 \mathrm{~kg}$ of medium loam soil, sampled from the plough layer. Soil $\mathrm{pH}$ in $\mathrm{KCl}$ (6.3) was determined together with the concentration of $\mathrm{N}^{-\mathrm{NO}_{3}}\left(1.4 \mathrm{mg} \mathrm{kg}^{-1} \mathrm{DM}\right), \mathrm{NH}_{4}-\mathrm{N}$ $\left(60.9 \mathrm{mg} \mathrm{kg}^{-1} \mathrm{DM}\right)$, and organic carbon, $\mathrm{C}_{\text {org }}$ $\left(17.1 \mathrm{~g} \mathrm{~kg}^{-1}\right)$. The content of some soil nutrients is presented in Table 1.

\section{Plant material}

In mid-March, 10 alfalfa seeds were planted in each of the pots at a depth of $1.5 \mathrm{~cm}$. After germination, when the plants had developed 3 leaves, a negative selection was carried out, leaving three plants that have developed the largest number of leaves in a pot. In the experiment different doses of Stymjod were applied with the following variants: $\mathrm{F}_{0.0 \%}$ - control treated with distilled water, $\mathrm{F}_{1.5 \%}$ - plants treated with $1.5 \%$ product, $\mathrm{F}_{3.0 \%}$ - plants treated with $3 \%$ product, $\mathrm{F}_{4.5 \%}$ - plants treated with $4.5 \%$ product. The plants were treated twice: during the six leaf stage and during the first-branch stage, using 50 $\mathrm{ml}$ of the solution per pot each time. According to Romanowska-Duda et al. (2018), Stymjod is a product obtained from the organic and mineral substrates in the cold plasma in nano-technology. It contains the optimal composition of macro and micronutrients as well as nano-iodine molecules.

Table 1. The content of selected chemical elements in the soil

\begin{tabular}{|l|c|}
\hline \multicolumn{1}{|c|}{ Chemical element } & Soil content $\left(\mathrm{mg} \mathrm{kg}^{-1} \mathrm{DM}\right)$ \\
\hline Phosphorus & 480 \\
\hline Magnesium & 100 \\
\hline Potassium & 130 \\
\hline Copper & 8.70 \\
\hline Zinc & 22.3 \\
\hline Boron & 2.3 \\
\hline Manganese & 191 \\
\hline Iron & 1570 \\
\hline
\end{tabular}


The iodine molecules activate cell metabolism, which causes an intensive growth and development of plants and increases their resistance to biotic and climatic factors. The chemical composition of Stymiod is presented in Table 2.

The following features were analysed: the number of stems per pot, the number of leaves per pot, fresh and dry weight of plants $\left(\mathrm{g} \mathrm{pot}^{-1}\right)$, fresh and dry weight of stems $\left(\mathrm{g} \mathrm{pot}^{-1}\right)$, fresh and dry weight of leaves $\left(\mathrm{g} \mathrm{pot}^{-1}\right)$, fresh and dry weight of roots $\left(\mathrm{g} \mathrm{pot}^{-1}\right)$. The harvest of alfalfa plants and morphological measurements were performed at $40-50 \%$ flowering.

\section{Statistical analysis}

The results were processed statistically using analysis of variance, and the differences between means were checked with Tukey's test at $\mathrm{HSD}_{0.05}$. Means marked with the same letters are not significantly different. The Statistica 13 - 2017.3 software package was used to conduct all calculations.

\section{RESULTS AND DISCUSSION}

In the present experiment (Figure 1) Stymjod in the form of spraying fluid significantly increased the number of hybrid alfalfa stems. It was the largest for alfalfa treated with $4.5 \%$ fertilizer concentration. The plants treated with this dose produced 27 stems per pot, which was greater by about $22 \%$ than the number from control

Table 2. The content of mineral and organic compounds in the Stymjod

\begin{tabular}{|l|c|}
\hline \multicolumn{1}{|c|}{ Names of mineral constituents } & Content (\%) \\
\hline Nitrogen $-\mathrm{N}$ & 6.3 \\
\hline Phosphorus oxide $(\mathrm{V})-\mathrm{P}_{2} \mathrm{O}_{5}$ & 4.58 \\
\hline Photassium oxide $-\mathrm{K}_{2} \mathrm{O}$ & 6.42 \\
\hline Magnesium oxide $-\mathrm{mgo}$ & 1.69 \\
\hline Sulfuric acid residue $(\mathrm{VI})-\mathrm{SO}_{4}$ & 1.6 \\
\hline Iron - Fe & 0.14 \\
\hline Manganese - Mn & 0.16 \\
\hline Cooper - Cu & 0.17 \\
\hline Molybdenum - Mo & 0.028 \\
\hline Zinc - Zn & 0.42 \\
\hline Bordon - B & 0.086 \\
\hline Humic acids & 3.3 \\
\hline $\begin{array}{l}\text { Organic substance (including amino } \\
\text { acids) }\end{array}$ & 56.8 \\
\hline $\mathrm{I}_{\mathrm{n}}^{+}:$aqueous iodine concentrate & 0.0025 \\
\hline
\end{tabular}

treatment. The application of $1.5 \%$ and $3 \%$ concentrations did not significantly affect the growth of this feature, and the number of stems obtained with these doses was similar to that in control pots.

Stymjod applied at various concentrations significantly affected the number of alfalfa leaves (Figure 2). The largest number was produced with the Stymjod concentration of $4.5 \%$. It was 751 per pot and was approximately $36.5 \%$ greater than the number of leaves in control. The plants responded both to $1.5 \%$ and $3 \%$ concentrations with a similar number of leaves. It was 640 per pot for the former and 644 for the latter, which was, respectively, $25 \%$ and $26 \%$ greater than in control.

The fresh weight of hybrid alfalfa stems was also dependent on the iodine concentration in the working fluid (Figure 3). The highest weight was obtained using the $3 \%$ concentration. It was $22.5 \mathrm{~g} \mathrm{pot}^{-1}$ and was greater than in control by about $58 \%$. Treating plants with the $1.5 \%$ and $4.5 \%$ concentrations did not contribute significantly to the growth of the fresh weight of stems, and it was comparable to that in control units.

The experimental results indicated (Figure 4) that the fertilizer also affected the fresh weight of leaves. The largest fresh weight of leaves was produced with the application of $4.5 \%$ Stymjod. This value was $17.5 \mathrm{~g} \mathrm{pot}^{-1}$ and was greater than in control by approximately $41 \%$. The fertilizer applied at the concentrations of $1.5 \%$ and $3 \%$ positively increased the fresh weight of leaves, but the effects in both cases were statistically insignificant.

The data presented in Figure 5 demonstrate that various values of the fresh weight of roots were obtained. Those values were dependent on the fertilizer concentration. Different Stymjod concentrations in the working fluid significantly affected the growth of alfalfa roots. The largest fresh weight was obtained by applying the $1.5 \%$ concentration. In this case it was $17.2 \mathrm{~g} \mathrm{pot}^{-1}$ and was greater than in control by $39.5 \%$. Treatment of hybrid alfalfa with the $3 \%$ and $4.5 \%$ concentrations contributed, in comparison with control, to a decrease in the fresh weight of roots produced by plants. The decline in relation to control was $27-31 \%$.

The analysis of the results showed that the Stymjod application significantly increased the dry weight of alfalfa stems (Figure 6), but various fertilizer concentrations did not differentiate it.

The largest dry weight of leaves (Figure 7) was obtained by treating plants with $4.5 \%$ concentration. It was greater than control by approximately 


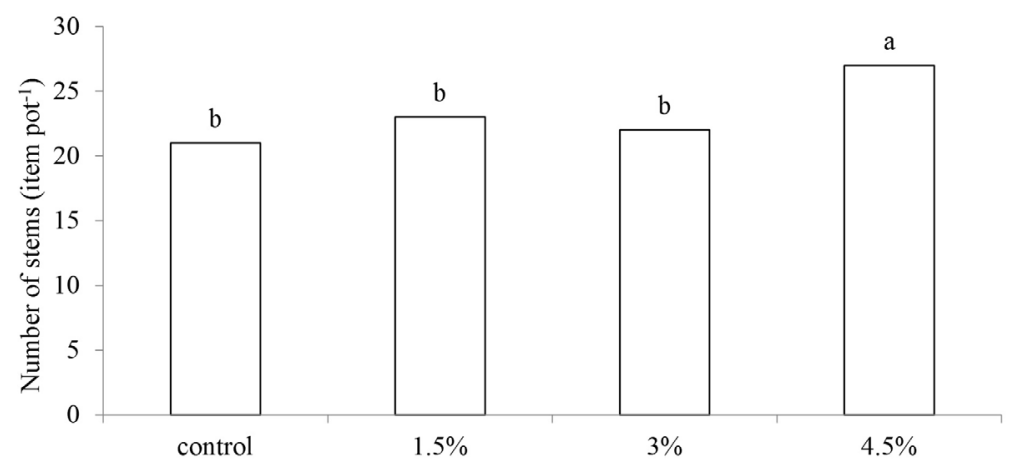

Figure 1. The effect of Stymjod concentrations on the number of hybrid alfalfa stems per pot *means in columns with the same letters do not differ significantly

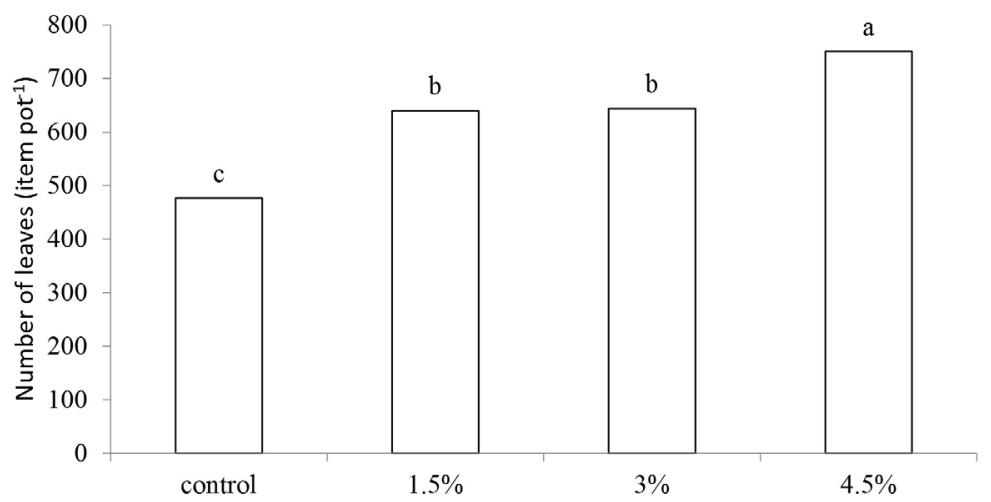

Figure 2. The effect of Stymjod concentrations on the number of hybrid alfalfa leaves per pot*means in columns with the same letters do not differ significantly

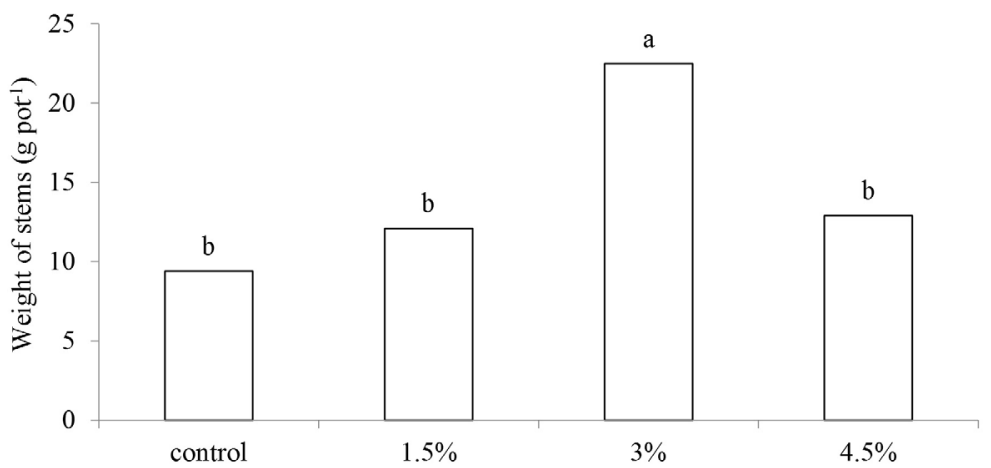

Figure 3. The effect of Stymjod concentrations on the fresh weight of alfalfa stems (g pot-1) *means in columns with the same letters do not differ significantly

$36 \%$ and amounted to $4.2 \mathrm{~g} \mathrm{pot}^{-1}$. The concentrations of $1.5 \%$ and $3 \%$ were less effective, but the weight increased in a statistically significant way, being $29 \%$ and $25 \%$ greater than in control units. The plants treated with the concentration of $1.5 \%$ developed the dry weight of leaves of about $3.8 \mathrm{~g}$ pot $^{-1}$. In turn, when treated with the concentration of $3 \%$, it was $3.6 \mathrm{~g} \mathrm{pot}^{-1}$.

The largest dry weight of roots (Figure 8) was produced using the $1.5 \%$ Stymjod concentration.
The weight of the dry matter in this case amounted to $3.8 \mathrm{~g} \mathrm{pot}^{-1}$ and was greater than in control by approximately $32 \%$. Both $3 \%$ and $4.5 \%$ concentrations affected the dry matter weight of hybrid alfalfa roots in a similar way, and it was smaller by approximately $31 \%$ and $27 \%$ than control results. The concentration of the fertilizer had a significant impact on the total fresh weight of hybrid alfalfa plants (Figure 9). The largest total weight was obtained by treating alfalfa with the Stymjod 


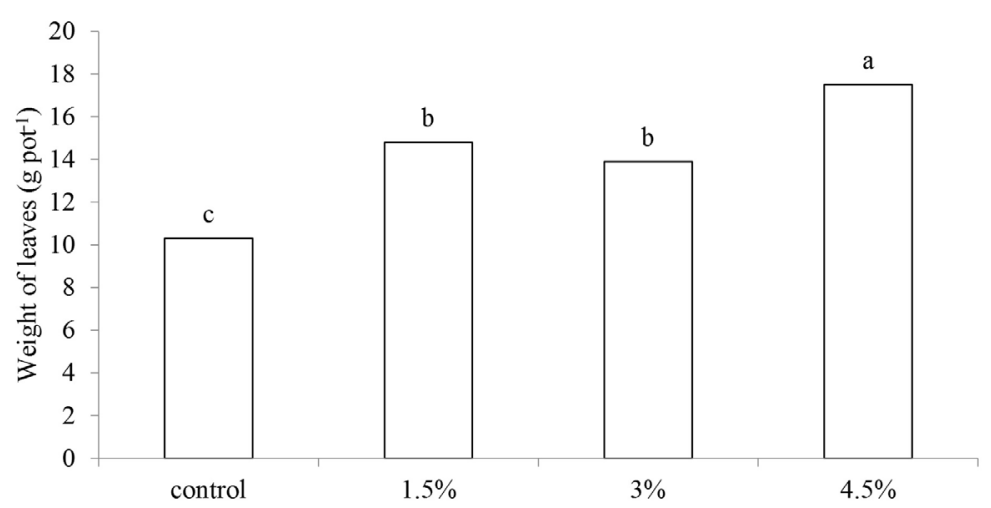

Figure 4. The effect of Stymjod concentrations on the fresh weight of alfalfa leaves (g pot-1) *means in columns with the same letters do not differ significantly

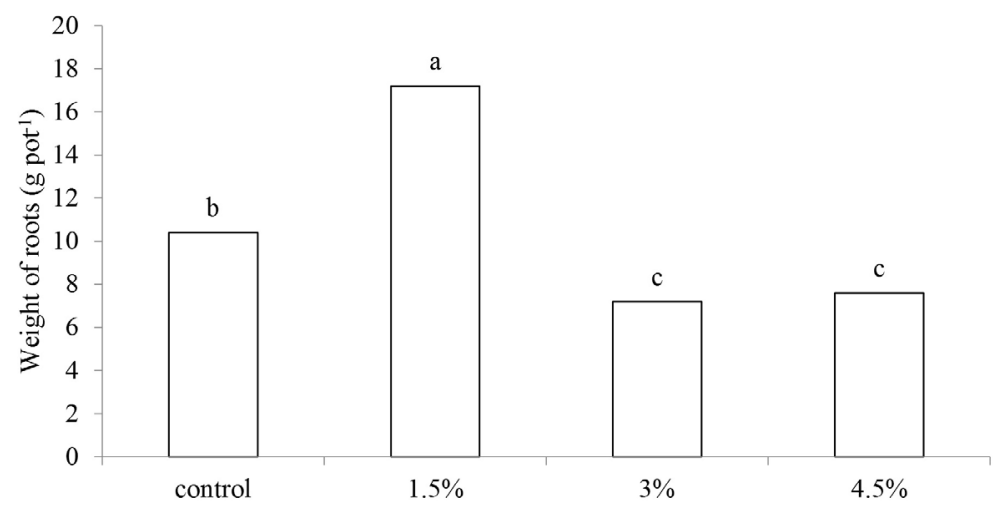

Figure 5. The effect of Stymjod concentrations on the fresh weight of alfalfa roots (g pot-1) *means in columns with the same letters do not differ significantly

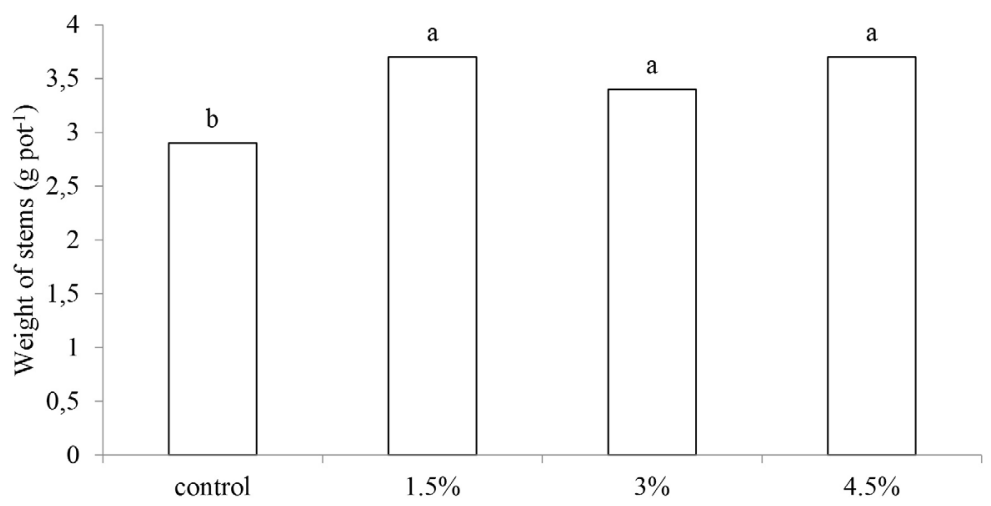

Figure 6. The effect of Stymjod concentrations on the dry weight of alfalfa stems (g pot-1) *means in columns with the same letters do not differ significantly

concentrations of $1.5 \%$ and $3 \%$, with $44.1 \mathrm{~g} \mathrm{pot}^{-1}$ and $43.6 \mathrm{~g} \mathrm{pot}^{-1}$ for $3 \%$, respectively. For the concentration of $1.5 \%$, the weight was approximately $32 \%$ greater than in control. In the case of $3 \%$ concentration it was more by about $31 \%$. Both of these concentrations equally raised the fresh weight of plants. The concentration of $4.5 \%$ also contributed to its growth. The fresh weight of plants on such units amounted to $38 \mathrm{~g} \mathrm{pot}^{-1}$, and in relation to control it increased by $21 \%$.

For all Stymjod concentrations in the working fluid, an increase in the alfalfa yield was observed. For the concentrations of $1.5 \%$ and $3 \%$ the yield increase was significantly larger than for $4.5 \%$ concentration. In addition, by applying a foliar Biojodis spray Smoleń (2009) increased 


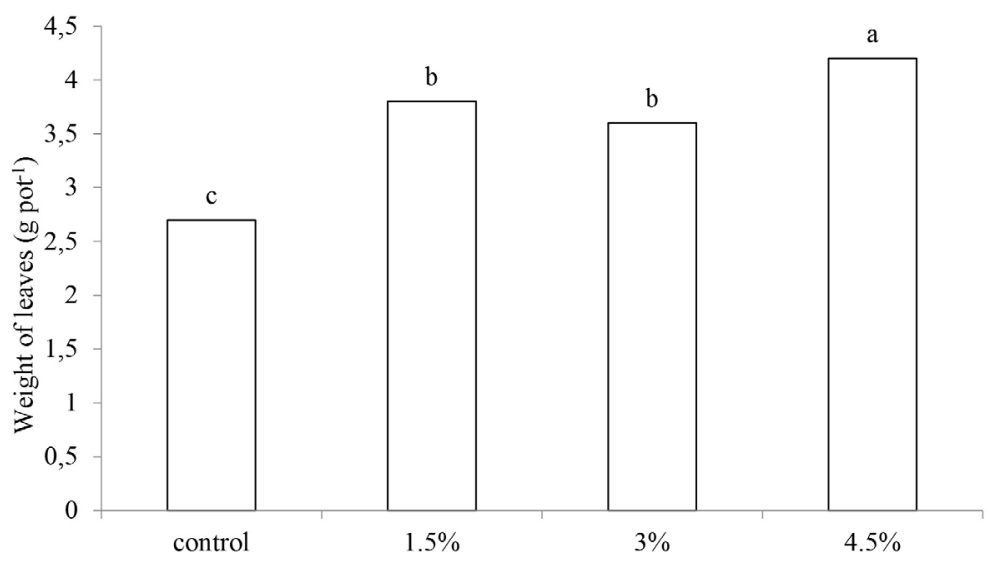

Figure 7. The effect of Stymjod concentrations on the dry weight of alfalfa leaves (g pot-1) *means in columns with the same letters do not differ significantly

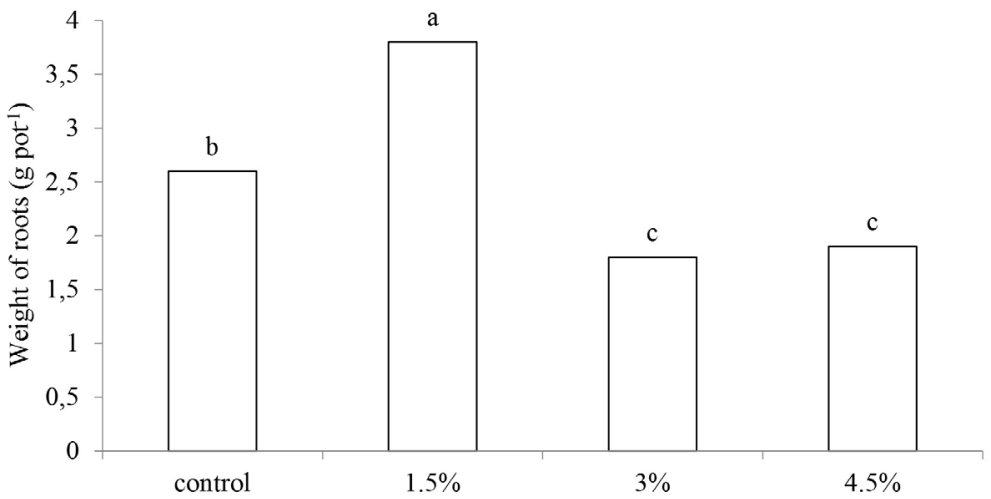

Figure 8. The effect of Stymjod concentrations on the dry weight of alfalfa roots (g pot-1) *means in columns with the same letters do not differ significantly

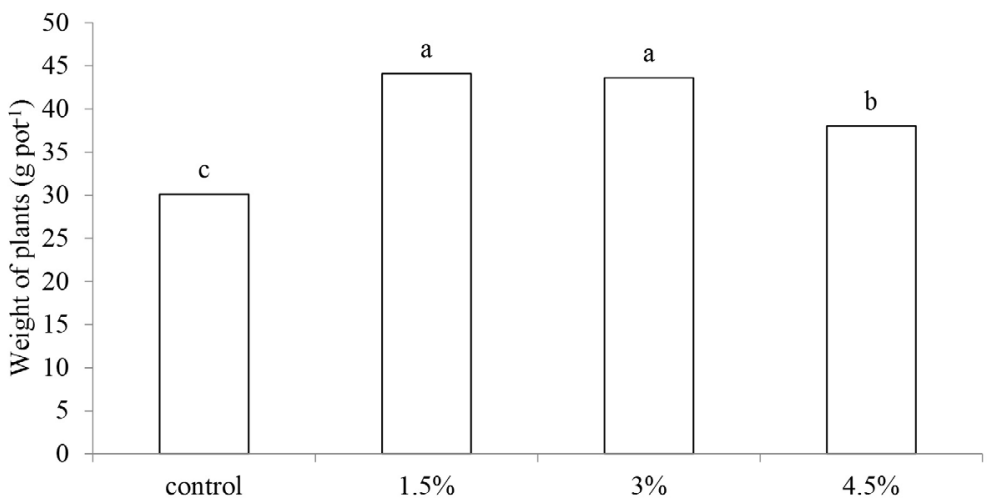

Figure 9. The effect of Stymjod concentrations on the total fresh weight of alfalfa plants (g pot-1) *means in columns with the same letters do not differ significantly

the yield of cabbage var. Chopin by $4-5 \%$ and cabbage var. Arivist by $12 \%$, and in the case of pickling cucumber varieties - by about $10 \%$ compared to control.

The largest gain in the alfalfa dry weight (Figure 10) was in the case of $1.5 \%$ concentration. It increased to $11.3 \mathrm{~g} \mathrm{pot}^{-1}, 27 \%$ greater than in control. In turn, treating plants with the concentration of $3 \%$ did not contribute significantly to an increase in the total dry weight of alfalfa; with the weight difference of $0.6 \mathrm{~g} \mathrm{pot}^{-1}$, which was approximately $7 \%$, it was comparable to control. The effect of $4.5 \%$ Stymjod was similar to the control results and to the effects of other concentrations. 


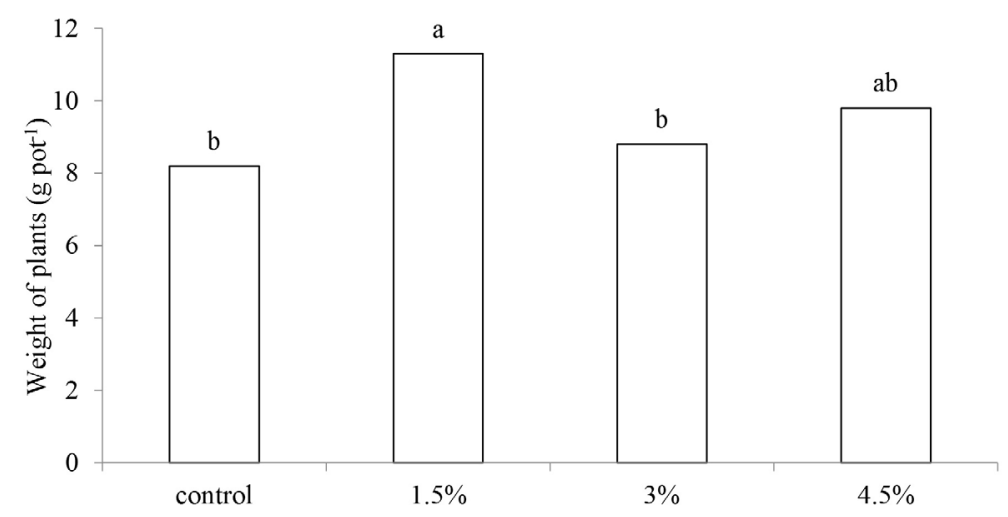

Figure 10. The effect of Stymjod concentrations on the dry weight of alfalfa plants (g pot-1) *means in columns with the same letters do not differ significantly

The weight obtained with $4.5 \%$ concentration was greater than control by approximately $16 \%$, i.e. by $1.6 \mathrm{~g} \mathrm{pot}^{-1}$, and smaller than on pots with $1.5 \%$ concentration by $13 \%$, i.e. by $1.5 \mathrm{~g} \mathrm{pot}^{-1}$.

In the case of hybrid alfalfa var. Kometa, the total weight of plant dry matter increased only when the $1.5 \%$ and $4.5 \%$ concentrations were applied, while the $3 \%$ concentration did not result in a substantial increase. In their studies Romanowska-Duda et al. (2018) found that sorghum plants were very sensitive to Stymjod. This fertilizer applied with the $0.1,0.7,1.5$, and $3 \%$ concentrations as foliar spray significantly increased the plant growth, physiological activity, greenness index, stomatal gas exchange (photosynthetic activity, transpiration, stomatal conductance, and the concentration of intercellular $\mathrm{CO}_{2}$ ), the activity of acid phosphatise, alkaline phosphatise, RNase, and total dehydrogenases. According to the authors, the yield increase of sorghum fresh and dry matter was an effect of the improvement of the above-mentioned plant physiological activity parameters. In addition, they also pointed out that the morphological results obtained from sorghum were in accordance with the overall information on the effects of Stymjod provided by its manufacturers. The authors indicated that Stymjod increased the weight of plants, improved their resistance to adverse weather conditions, and relieved the negative effects of stress. Piotrowski et al. (2016) believe that the stimulating effect of organic-mineral substances containing iodine on plant development and physiological activity may be caused not only by iodine, but also by macronutrients, micronutrients, amino acids, and other organic compounds present in such products as Stymjod.

\section{CONCLUSIONS}

1. The present studies demonstrated that Stymjod applied foliarly at $4.5 \%$ concentration significantly affected the growth of stems and leaf blades.

2. Only the $1.5 \%$ concentration increased the weight of fresh matter and dry matter of roots. The application of larger concentrations did not affect this feature.

3. The increase in the fresh matter weight of stems was caused by $3 \%$ concentration of the fertilizer only. However, dry matter weight increased for all fertilizer concentrations.

4. Foliar application increased the weight of fresh and dry matter of hybrid alfalfa for all Stymjod concentrations.

5. The experiment showed that the effects of Stymjod application to hybrid alfalfa depended on its dose. It is difficult, however, to clearly state which concentration produced the best results, so further research in this area is needed.

\section{Acknowledgements}

The research carried out under the theme No $357 / 13 / \mathrm{S}$ was financed by the science grant of the Ministry of Science and Higher Education - Poland.

\section{REFERENCES}

1. Blasco B., Rios J.J., Cervilla L.M., Sanchez-Rodriguez E., Ruiz J.M., Romero L. 2008. Iodine biofortification and antioxidant capacity of lettuce: potential benefits for cultivation and human health. Annals of Applied Biology, 152, 289-299. DOI: 10.1111/j.1744-7348.2008.00217.x. 
2. Dai J.L., Zhu Y.G., Huang Y.Z., Zhang M.L. 2006. Availability of iodide and iodate to spinach (Spinacia oleracea L.) in relation to total iodine in soil solution Plant Soil. Advances in Plant Physiology, 289(1-2), 301-308.

3. Gaweł E., Grzelak M. 2013. Protein-xanthophylls concentrate of lucerne in animal nutrition. Journal of Research and Application in Agriculture Engineering, 58(3), 137-142.

4. Godlewska A., Ciepiela G.A. 2018. Assessment of the effect of various biostimulants on Medicago $\mathrm{x}$ varia T. Martyn yielding and content of selected organic components. Applied Ecology and Environmental Research, 16(5), 5571-5581. DOI: 10.15666/aeer/1605_55715581.

5. Ilieva A., Vasileva V. 2013. Effect of mineral fertilization and manure on some characteristics in alfalfa (Medicago sativa L.). World Applied Sciences Journal, 26(5), 630-635. DOI: 10.5829/idosi. wasj.2013.26.05.13501.

6. Kallenbach R.L., Nelson C.J., Coutts J.H. 2002. Yield, quality, and persistence of grazing - and hay - type alfalfa under three harvest frequencies. Agronomy Journal, 94, 1094-1103. DOI: 10.2134/ agronj2002.1094.

7. Lu X., Ji S., Hou CH., Shen Y. 2017. Morphological development and dry weight distribution of alfalfa cultivars varying in fall dormancy under a shortterm cultivation system. Grassland Science, 63(1), 23-28. DOI: 10.1111/grs.12139.

8. Mackowiak C.L., Grossl P.R. 1999. Iodate and iodide effects on iodine uptake and partitioning in rice (Oryza sativa L.) grown in solution culture. Plant and Soil, 212, 135-143.

9. Peoples M. B. 2001. Legumes root nitrogen in cropping system nitrogen cycling. Graine Legume, 33, 8-9.

10. Pietrzak K., Grela E. 2013. The influence of proteinxanthophyll concentrate of alfalfa on growth performance and carcass value of growing-finishing pigs. Annales Universitatis Mariae Curie-Skłodowska. Sectio EE: Zootechnica, 31(3), 10-17.

11. Piotrowski K., Romanowska-Duda Z., Grzesik M. 2016. How Biojodis and Cyanobacteria alleviate the negative influence of predicted environmental constraints on growth and physiological activity of corn plants. Polish Journal of Environmental Studies, 25(2), 741-751. DOI: 10.15244/pjoes/60894.

12. Romanowska-Duda Z., Grzesik M., Janas R. 2018. Stimulatory impact of Stymjod on sorghum plant growth, physiological activity and biomass production in field conditions. In: Mudryk K., Werle S. (Eds) Renewable Energy Sources: Engineering, Technology, Innovation. Springer Proceedings in Energy. Springer, Cham. DOI: 10.1007/978-3-319-72371-6 24.

13. Shen Y., Jiang H., Zhai G., Cai Q. 2013. Effects of cutting height on shoot regrowth and forage yield of alfalfa (Medicago sativa L.) in a shortterm cultivation system. Grassland Science. 59(2), 73-79.
DOI: $10.1111 /$ grs. 12014 .

14. Smolen S. 2009. The effect of iodine and nitrogen fertilization on the mineral composition of the carrot. Environmental Protection and Natural Resources, 40, 270-277.

15. Sosnowski J., Jankowski K., Malinowska E., Truba M. 2017. The effect of Ecklonia maxima extract on Medicago x varia T. Martyn biomass. Journal of Soil Science and Plant Nutrition, 17(3), 770-780. DOI: 10.4067/S0718-95162017000300016.

16. Sosnowski J., Malinowska E., Jankowski K., Król J., Redzik P. 2019. An estimation of the effects of synthetic auxin and cytokinin and the time of their application on some morphological and physiological characteristics of Medicago x varia T. Martyn. Saudi Journal of Biological Sciences, 26(1), 66-73. DOI: org/10.1016/j.sjbs.2016.12.023

17. Strzetelski P., Smoleń S., Rożek S., Sady W. 2010a. The effect of differentiated fertilizationand foliar application of iodine on yielding and antioxidant properties in radish (Raphanussativus L.) plants. Ecological Chemistry and Engineering A, 17(9), 1189-1195. DOI: baztech/element/bwmeta1.element.baztech-article-BPG8-0062-0002.

18. Strzetelski P., Smoleń S., Rożek S., Sady W. 2010 b. The effect of diverse iodine fertilizationon nitrate accumulation and content of selected compounds in radish plants (Raphanussativus L.). ACTA Scientarum Polonorum Horticulture, 9(2), 65-73.

19. Vasileva V., Kostov O., Vasilev E., Athar M. 2011. Effect of mineral nitrogen fertilization on growth characteristics of lucerne under induced water deficiency stress. Pakistan Journal of Botany, 43(6), 2925-2928.

20. Weng H.X., Hong C.L., Qin Y.C., Yan A.L., Xie L.L. 2008. Transfer of iodine from soil to vegetables by applying exogenous iodine. Agronomy for Sustainable Development, 28(4), 575-583. DOI: 10.1051/agro:2008033.

21. WHO. 2007. Reducing salt intake in populations. Report of a WHO Forum and Technical Meeting. Geneva. World Health Organization.

22. Wierzbińska J., Smoleń S., Sady W. 2011. Effect of iodine from on the efficiency of its uptake, yield and nitrogen metabolism of tomato plants cultivated in nft system. EPISTEME, 1(12), 336-370.

23. Wilczek M., Koper R., Ćwintal M., KorniłłowiczKowalska T. 2005a. Germination capacity and health status of alfalfa sedes after laser treatment. International Agrophysics, 19(1), 85-89.

24. Wilczek M., Koper R., Ćwintal M., KorniłłowiczKowalska T. 2005b. Germination capacity and health status of hybrid alfalfa seeds after laser treatment. International Agrophysics, 19(3), 257-261.

25. Zhu Y-G., Huang Y.-Z., Hu Y., Liu Y.-X. 2003. Iodine uptake by spinach (Spinacia oleracea L.) plants grown in solution culture: effects of iodine species and solution concentrations. Environment International, 29, 33-37. DOI: 10.1016/S0160-4120(02)00129-0. 